\title{
Diversity and endemism in cold waters of the South Atlantic: contrasting patterns in the plankton and the benthos*
}

\author{
DEMETRIO BOLTOVSKOY ${ }^{1,2,3}$, NANCY CORREA ${ }^{4}$ and ANDRES BOLTOVSKOY ${ }^{2,5}$ \\ ${ }^{1}$ Departamento de Ecología, Genética y Evolución, Facultad de Ciencias Exactas y Naturales, Universidad de Buenos \\ Aires, 1428 Buenos Aires, Argentina. E-mail: demetrio@bg.fcen.uba.ar \\ ${ }^{2}$ Consejo Nacional de Investigaciones Científicas y Técnicas, Argentina. \\ ${ }^{3}$ Museo Argentino de Ciencias Naturales "Bernardino Rivadavia”, Av. Angel Gallardo 470, \\ 1405 Buenos Aires, Argentina. \\ ${ }^{4}$ Servicio de Hidrografía Naval, Av. Montes de Oca 2124, 1271 Buenos Aires, Argentina. \\ ${ }^{5}$ Facultad de Ciencias Naturales y Museo, Universidad Nacional de La Plata, 1900 La Plata, Argentina.
}

\begin{abstract}
SUMMARY: In total, $c a .7000$ zooplanktonic species have been described for the World Ocean. This figure represents less than $4 \%$ of the total number of known marine organisms. Of the 7000 zooplanktonic species world-wide, some $60 \%$ are present in the South Atlantic; about one third of the latter have been recorded in its Subantarctic waters, and ca. 20\% south of the Polar Front. When compared with those of benthic animals, these figures indicate that proportions of the overall inventories that are present in the cold waters are almost two times higher among the zooplankton. In agreement with this pattern, the proportions of Antarctic endemics in the benthos are very significantly higher than those in the plankton. For the water-column dwelling animals, the Polar Front boundary is more important than the Tropical-Subtropical limit, but almost equivalent to the Subtropical-Transitional limit, and weaker in biogeographic terms than the Transitional-Subantarctic boundary. Some of the implications of these dissimilarities, both for ecological theory and for resource allocation strategies, are discussed.
\end{abstract}

Keywords: biodiversity, biogeography, zooplankton, benthos, Antarctic, Subantarctic.

RESUMEN: DiVERSIDAD Y ENDEMISMO EN LAS AGUAS FRíAS DEL ATLÁNTICO SUR: CONTRASTES ENTRE EL PLANCTON Y EL BENTOS. - Para el Océano Mundial se ha descrito un total de 7000 especies de zooplancton. Esta cifra representa menos del $4 \%$ de los organismos marinos conocidos. De las 7000 especies zooplanctónicas del mundo, cerca del $60 \%$ está presente en el Atlántico Sur. De este $60 \%$, alrededor de un tercio fueron registradas en aguas subantárticas, y ca. $20 \%$ al sur del Frente Polar. La comparación de estos valores con los de los animales bentónicos indica que, con respecto al total de especies descritas, en el zooplancton la proporción que habita las aguas frías duplica a las del bentos. En concordancia con ello, la proporción de endemismos es mucho más alta en el bentos que en el plancton. Para los animales que habitan la columna de agua la barrera del Frente Polar es más importante que el Límite Tropical-Subtropical, pero casi igual que el Límite Subtropical-Transición, y menos importante en términos biogeográficos que el Límite Transición-Subantártico. Se discuten algunas implicaciones de estas diferencias en términos de teoría ecológica y de las estrategias de distribución de los recursos.

Palabras clave: biodiversidad, biogeografía, zooplancton, bentos, Antártida, subantártico. 


\section{DATA}

Zooplanktonic species numbers and distribution ranges presented in this paper are chiefly based on the extensive compilations produced for the recent review "South Atlantic Zooplankton" (Boltovskoy, 1999a). The two volumes of this work included a total of 28 holo- and meroplanktonic taxa, but due to differences in the current knowledge of these animals, the degree and detail of coverage varied significantly. Most estimates and comparisons discussed use 15 of these 28 groups (encompassing 1305 species), whose distribution patterns between the equator and $60^{\circ} \mathrm{S}$ are reasonably well defined, and whose life cycle is restricted to the water column (holozooplankton). Conclusions rely heaviest on data summarised by Alder (1999) (Tintinnoinea), Angel (1999) (Ostracoda), Boltovskoy (1999b) (Radiolaria Polycystina), Casanova (1999) (Chaetognatha), Esnal (1999) (Appendicularia), Esnal and Daponte (1999) (Salpida), Gibbons et al. (1999) (Euphausiacea), Kemlevon Mücke and Hemleben (1999) (Foraminifera), Kling and Boltovskoy (1999) (Radiolaria Phaeodaria), Murano (1999) (Mysidacea), Nesis (1999) (Cephalopoda), Pugh (1999) (Siphonophorae), Spoel and Dadon (1999) (Pteropoda), Thuesen and Fernández Álamo(1999) (Polychaeta), and Vinogradov (1999) (Amphipoda).

It should be emphasised that the latitudinal distribution ranges tabulated are in some cases rather rough estimates based on ancillary and interpolated information. This introduces some uncertainty in the figures presented, for which reason most numbers should be considered as preliminary estimates. Nevertheless, with the framework of the comparisons drawn, we contend that the general patterns presented and contrasts with the benthic realm are valid.

\section{BIODIVERSITY OF MARINE PLANKTON AND BENTHOS: THE WORLD OCEAN AND THE ANTARCTIC TODAY}

So far, the World Ocean has yielded approximately 7000 species of zooplankton (Boltovskoy et al., 2003; see Table 1), and 4000 of phytoplankton (Sournia et al., 1991).

Table 1 illustrates the distribution of the zooplanktonic taxa with estimated figures for the World Ocean and for the South Atlantic. On the basis of subsets of selected groups we also calculated how many of the species recorded in the South Atlantic

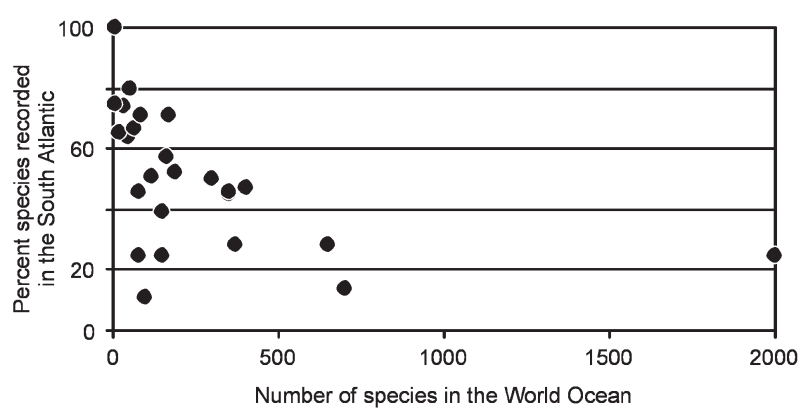

FIG. 1. - Proportions of species recorded in the South Atlantic for 26 zooplanktonic groups as a function of their overall totals known for the World Ocean (based on data from Table 1).

as a whole $\left(0\right.$ to $60^{\circ} \mathrm{S}$, American to African coasts) are present in its warm waters (Tropical or Equatorial and/or Subtropical, approximately between 0 and $35^{\circ} \mathrm{S}$ ), in the Subantarctic domain (approximately $45-50^{\circ} \mathrm{S}$; excluded are the Transitional waters, roughly between 35 and $45^{\circ} \mathrm{S}$ ), and in the Antarctic waters (south of 47 to $60^{\circ} \mathrm{S}$, depending on longitude). We anticipate that for most of these groups the precision of the numbers shown is around $\pm 20 \%$.

Estimates of the presence of world species in the South Atlantic are very preliminary because the data are significantly biased by two factors: (1) differences in the natural diversity of the groups encompassed, and (2) the degree of knowledge on them in the South Atlantic. In general terms, lower precision is associated with higher diversity values because of the higher effort needed to cover the more speciose groups. This is clearly shown in Figure 1, where a marked trend of lower percentages with higher overall species numbers is seen. The degree of coverage of the various groups in the South Atlantic, in turn, also introduces a significant bias: although some South Atlantic plankton taxa, like the Foraminifera, have been well covered by both local and international experts for many years, many others (e.g. Acantharia, Phaeodaria, Ciliophora, Nemertina and Mysidacea) have very seldom been investigated in these waters. Thus, while the overall average of World species recorded in the South Atlantic is around 37\% (Table 1), when the groups are sorted according to their (subjectively perceived) degree of coverage in the South Atlantic the figures range between as high as $80 \%$ for the very well known Foraminifera to as low as $35 \%$ for the very poorly known taxa.

These considerations suggest that the "real" proportion of World Ocean zooplanktonic species that inhabit the South Atlantic is significantly higher than the figure shown in Table 1, probably around $60-70 \%$. 
TABLE 1. - Estimated numbers of marine zooplanktonic species for the World Ocean and for the South Atlantic (modified from Boltovskoy, 2000). Biogeographic boundaries indicated are from Boltovskoy et al. (1999) and references therein.

\begin{tabular}{|c|c|c|c|c|c|c|}
\hline Group & $\begin{array}{l}\text { Number of } \\
\text { species } \\
\text { worldwide }\end{array}$ & $\begin{array}{c}\text { Number of } \\
\text { species [and } \\
\text { percentage of } \\
\text { World total] in } \\
\text { the South Atlantic }\end{array}$ & $\begin{array}{c}\text { Percentage } \\
\text { of South Atlantic } \\
\text { species present } \\
\text { in warm waters } \\
\text { (Tropical and/ } \\
\text { or Subtropical) }(*)\end{array}$ & $\begin{array}{l}\text { Percentage } \\
\text { of South } \\
\text { Atlantic } \\
\text { species present } \\
\text { in Subantarctic } \\
\text { waters }(*)\end{array}$ & $\begin{array}{c}\text { Percentage of } \\
\text { South Atlantic } \\
\text { species present } \\
\text { in Antarctic } \\
\text { waters }(*)\end{array}$ & $\begin{array}{l}\text { Degree of } \\
\text { knowledge in } \\
\text { the South } \\
\text { Atlantic }\end{array}$ \\
\hline Foraminifera & 49 & $39[80]$ & 97 & 28 & 19 & Very good \\
\hline Acantharia & 150 & & & & & Very poor \\
\hline Radiolaria Polycystina & 350 & $160[46]$ & 90 & 26 & 23 & Poor \\
\hline Radiolaria Phaeodaria & 350 & $158[45]$ & 70 & 33 & 43 & Very poor \\
\hline Ciliophora & 150 & $58[39]$ & & & & Very poor \\
\hline Tintinnida & 300 & $151[50]$ & 60 & 17 & 16 & Fair \\
\hline Hydromedusae & 650 & $185[28]$ & & & & Fair \\
\hline Siphonophora & 190 & $98[52]$ & 92 & 41 & 28 & Fair \\
\hline Scyphozoa & 150 & $38[25]$ & & & & Poor \\
\hline Ctenophora & 80 & $20[25]$ & & & & Poor \\
\hline Nemertini & 97 & $11[11]$ & & & & Very poor \\
\hline Polychaeta & 120 & $61[51]$ & 87 & 33 & 31 & Poor \\
\hline Heteropoda & 35 & $26[74]$ & & & & Fair \\
\hline Pteropoda & 160 & $91[57]$ & 86 & 16 & 9 & Good \\
\hline Cephalopoda & 370 & $103[28]$ & 92 & 18 & 8 & Very poor \\
\hline Cladocera & 8 & $8[100]$ & & & & Good \\
\hline Ostracoda & 169 & $120[71]$ & 95 & 37 & 21 & Fair \\
\hline Copepoda & 2000 & $505[25]$ & & & & Poor \\
\hline Mysidacea & 700 & $96[14]$ & 66 & 38 & 8 & Very poor \\
\hline Amphipoda & 400 & 188 [47] & 89 & 26 & 23 & Very poor \\
\hline Euphausiacea & 86 & $61[71]$ & 88 & 12 & 7 & Good \\
\hline Larvae of Brachyura & -- & 197 & & & & Poor \\
\hline Chaetognatha & 80 & $37[46]$ & 88 & 31 & 16 & Good \\
\hline Appendicularia & 64 & $43[67]$ & 84 & 63 & 40 & Good \\
\hline Pyrosomatida & 8 & $6[75]$ & & & & Very poor \\
\hline Doliolida & 17 & $11[65]$ & & & & Fair \\
\hline Salpida & 45 & $29[64]$ & 79 & 24 & 17 & Very good \\
\hline TOTAL & 6778 & 2500 [37] & & & & \\
\hline
\end{tabular}

(*) Figures based on subsets of the data including only those species for which distributional information is sufficient to allow these estimates.

When one compares the overall diversity of plankton with that of other communities, the first major contrast that strikes one's attention is the wide differences in biodiversity. As noticed above, zooplankton comprises around 7000 species, whereas non-planktonic marine animals, chiefly the benthos, range from 180,000 to 200,000 species (Zenkevitch, 1960; Briggs, 1996), with some estimates running into the millions (e.g. Grassle and Maciolek, 1992). The Antarctic benthos alone includes over 30004000 recorded species (Arntz et al., 1997; Clarke and Johnston, 2003), with estimates of up to 11,000 17,000 expected species for the continental shelf alone (Gutt et al., 2004).

A second interesting contrast between the plankton and the benthos is found in the proportions of overall species that are present south of the Polar Front. Using historical data for selected benthic invertebrates showing the highest species richness in the Southern Ocean, Clarke and Johnston (2003) estimated that Antarctic waters host between 17.5\%
(Pycnogonida) and 1\% (Gastropoda) of the world totals. The average for their values was around $7 \%$ (Fig. 2). A similar analysis for 15 zooplanktonic groups considering Antarctic waters of the Atlantic sector alone yields an average of $10 \%$, with values ranging between 27\% (Appendicularia) and 1\% (Mysidacea) (Fig. 2).

These figures, as well as other distributional traits (see below), strongly suggest that detachment from the bottom results in wider geographic ranges and lower degrees of endemism. Interestingly, for the planktonic groups illustrated in Figure 2, Cephalopoda and Mysidacea show the lowest proportions of species in Antarctic waters; planktonic Cephalopoda are largely comprised by the free-drifting paralarvae of benthic adults (Nesis, 1999), whereas most Mysidacea are benthopelagic organisms (Murano, 1999). The Amphipoda, in which some degree of association with the bottom is also common (Vinogradov, 1999), are also located on the right hand of the graph (Fig. 2). 

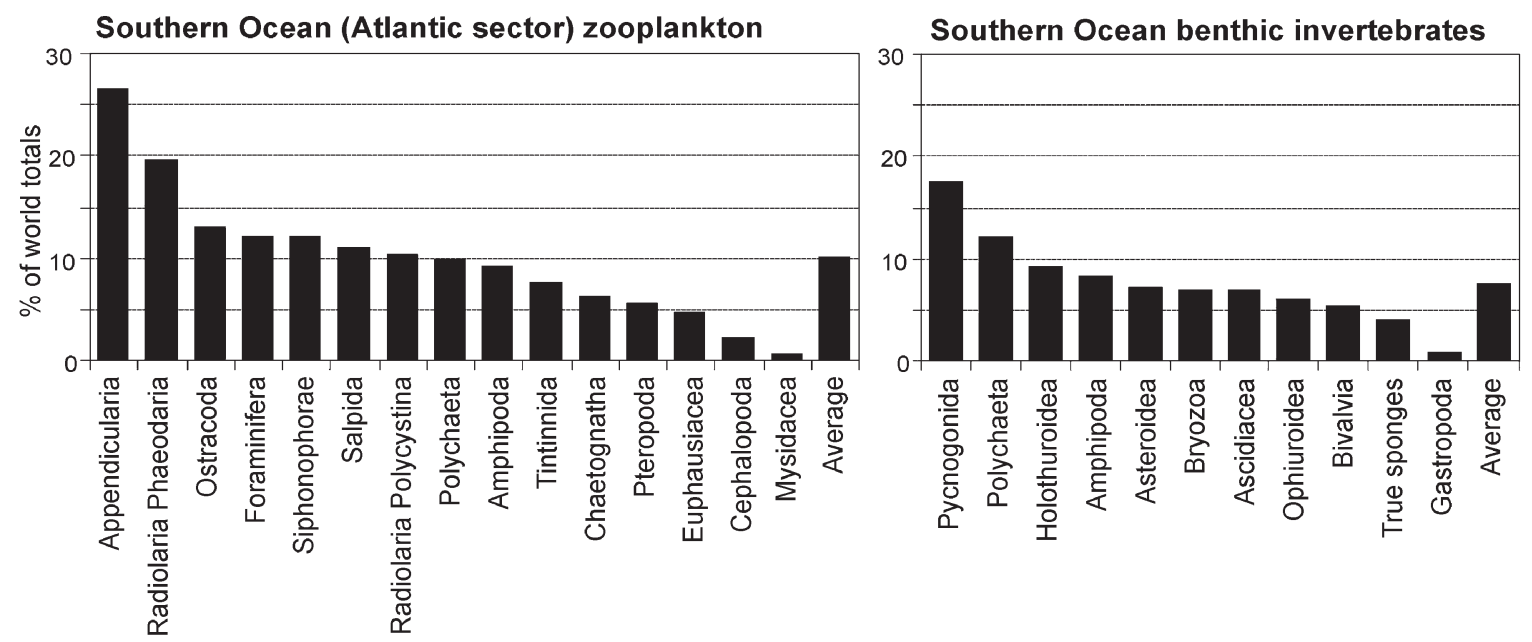

FIG. 2. - Zooplanktonic species described for the Southern Ocean (Atlantic sector) as a fraction of the world totals, as compared with similar values for the benthic invertebrate taxa, showing the highest species richness in the Southern Ocean (benthic invertebrate data from Clarke and Johnston, 2003).

It should be emphasised that association with the substrate affects not only the proportion of Antarctic species but also the geographic ranges of distribution worldwide. Of the approximately 700 mysid species known, only 96 (14\%) have been recorded in the South Atlantic (Murano, 1999 and pers. comm.; see Table 1). Comparison of mysid vs. euphausiid world wide distribution patterns also points to the same trend where the chiefly coastal and shallow water mysids have much more circumscribed geographic ranges than the predominantly pelagic, open-ocean euphausiids (Angel, 1996). It is suggested that links with the bottom makes mysid ranges depend as much on currents and water masses, as on topographic features, resulting in more constrained areal dispersion patterns. A similar trend is also shown by the Hydromedusae, whose life cycle includes a benthic stage. Over $75 \%$ of the 197 species recorded in the South Atlantic inhabit shelf or slope waters and many of them are unable to cross the Atlantic. Of the 109 species present along the Atlantic coasts of Africa, 45 (41\%) are absent on the American side of this ocean, whereas 77 (55\%) of the 141 American species have not been recorded on the eastern side (Bouillon, 1999). Benthic stages in their life cycle are also probably responsible for the fact that South Atlantic waters host less than $30 \%$ of the inventory of the Hydromedusae of the World Ocean (Bouillon, 1999) (as opposed to $c a$. $60 \%$ for zooplankton as a whole, see above).

As opposed to terrestrial and freshwater habitats, the oceanic realm is typically characterised by few and often diffuse distributional barriers. To some degree this applies to all marine biotopes, although communities associated with the bottom can be affected by small-scale changes in the type of substrate, sill and bottom depth, etc., which in turn results in smaller areas and better defined biogeographic divisions and higher chances for reproductive isolation. Communities that dwell in the water column, on the other hand, typically lack these physical discontinuities, to the point that the process of speciation in the plankton itself, which has been the subject of interest and debate for at least half a century (e.g. Hutchinson, 1961), is still a largely unresolved issue. This is not only a practical problem with important implications for sampling strategy and design, but also a major issue in ecological theory. The tenets of modern ecology, including competitive exclusion and forced extinction and speciation, which have been formulated for physically structured, typically terrestrial ecosystems, are often not applicable to marine plankton (Venrick, 1986). The fact that, in the entire (epipelagic) Pacific Ocean, an area spanning over 180 million square kilometres, only 8 distinct planktonic provinces are recognised (McGowan, 1974) is a result of both the scarcity of species and the homogeneity of their makeup over vast areas (Bé and Tolderlund, 1971; Pierrot-Bults and Spoel, 1979; Hemleben et al., 1989; McGowan and Walker, 1993; Angel, 1996).

\section{BIODIVERSITY OF MARINE PLANKTON AND BENTHOS: FUTURE TRENDS FOR THE WORLD OCEAN AND THE ANTARCTIC}

The above reviewed specific inventories are almost exclusively based on morphological criteria, which underestimate the true diversity of the organ- 
isms concerned. Indeed, for many marine planktonic protists with fossilizable remains (coccolithophorids, diatoms, foraminifers, radiolarians) circum-global distributions and very long stratigraphic ranges have been reported, which conflicts with their often very high turnover rates. The sequencing of various genes has shown that many of these morphological species are, in fact, monophyletic assemblages of sibling species which diverged several million years ago (De Vargas et al., 2004). In some instances these siblings have been found to depict allopatric distribution ranges either temporally or geographically. A very nice example of cryptic speciation in the marine plankton was recently published by De Vargas et al. (1999). These authors found that one of the most distinctive planktonic foraminifers, Orbulina universa, which has always been regarded as a single species, is in fact a complex of three cryptic species whose distribution is correlated to hydrographic provinces, and particularly to the concentration of chlorophyll $a$.

Morphologically cryptic, but genetically distinctive, species of zooplankton are being found with increasing frequency (e.g., Bucklin et al. 1996, 2003, Goetze 2003) and will probably prove to be the norm across a broad range of taxa. Many putative cosmopolitan species may comprise morphologically similar, genetically distinct sibling species, with discrete geographic distributions, but how many cryptic species are present is currently unknown, even for well-known zooplankton groups (CMarZ, 2004).

Future work, however, will not always tend to enlarge existing inventories. While new species will be erected through genetic studies, many currently known ones will be invalidated as a result of them being synonymised. This will most probably affect speciose groups whose taxonomic systems are in a serious state of disarray, like the radiolarians (polycystines and pheodarians), the acantharians, and the tintinnids. The literature on these organisms is plagued with synonyms, to the point that in many cases binary names alone have little or no meaning (Boltovskoy, 1998; Boltovskoy et al., 2003). This is partly due to problems arising from the use of poorly preserved materials and the analysis of skeletal (radiolarians, acantharians) or lorical (tintinnids) features only (Boltovskoy, 2000).

Nevertheless, the general consensus is that current zooplanktonic inventories are likely to increase rather than to shrink. However, even if every known species proves to be an assemblage of 3 or 4 mor- phologically cryptic siblings, the overall number of zooplanktonic species in the World Ocean will still remain below 20,000-30,000, which is at least one order of magnitude lower than the number of already described marine non-planktonic species (see above). Moreover, if benthic inventories are corrected for morphologically cryptic, so far undescribed species (e.g. see Held, 2005), the unbalance between biodiversity in the plankton and in the benthos will increase several-fold.

A useful approach to predicting the development of specific inventories is the analysis of the temporal trends in species descriptions, whereby rapidly climbing curves could indicate an incompletely documented fauna, whereas flat curves may suggest that the proportion of undescribed species is low (Costello et al., 1996; Paxton, 1998; Clarke and Johnston, 2003). We compared such curves for two conspicuous and very well-researched groups of vertebrates (Primates and Reptilia), 1599 zooplanktonic species (several groups) recorded in the South Atlantic, and three groups of Antarctic benthic invertebrates (Fig. 3 ). As expected, the vertebrates show very flat curves because over $70 \%$ of the current inventories were reached by 1829 (Reptilia) to 1863 (Primates). The zooplankton depicts an intermediate shape with a significant decrease in species description rates after around 1910, when $70 \%$ of the inventory was attained. Finally, the Antarctic benthic invertebrates show typically climbing curves, with no indication of an imminent saturation.

These results confirm the above conclusion that differences between species richness in the plankton and in the benthos are not an artefact due to unbalanced knowledge, and that the gap is likely to increase as we get closer to accounting for the overall biodiversity of the marine fauna.

\section{THE POLAR FRONT AS A BIOGEOGRAPHIC BOUNDARY AND ANTARCTIC ENDEMISM}

The Polar Front is one of the most characteristic features of the Southern Ocean. Its position may be defined by the northern boundary of cold ( -1.5 to $2{ }^{\circ} \mathrm{C}$ ) near-surface waters formed by winter cooling (Peterson and Stramma, 1991), or by the northern extent of the $2{ }^{\circ} \mathrm{C}$ isotherm at $2000 \mathrm{~m}$ (Botnikov, 1963). At the surface, this circumpolar, meandering feature, characterised by a very sharp $\left(2-3^{\circ} \mathrm{C}\right.$ in $10-$ 20 miles) temperature gradient, separates the Subantarctic zone from the Antarctic zone. This front is 

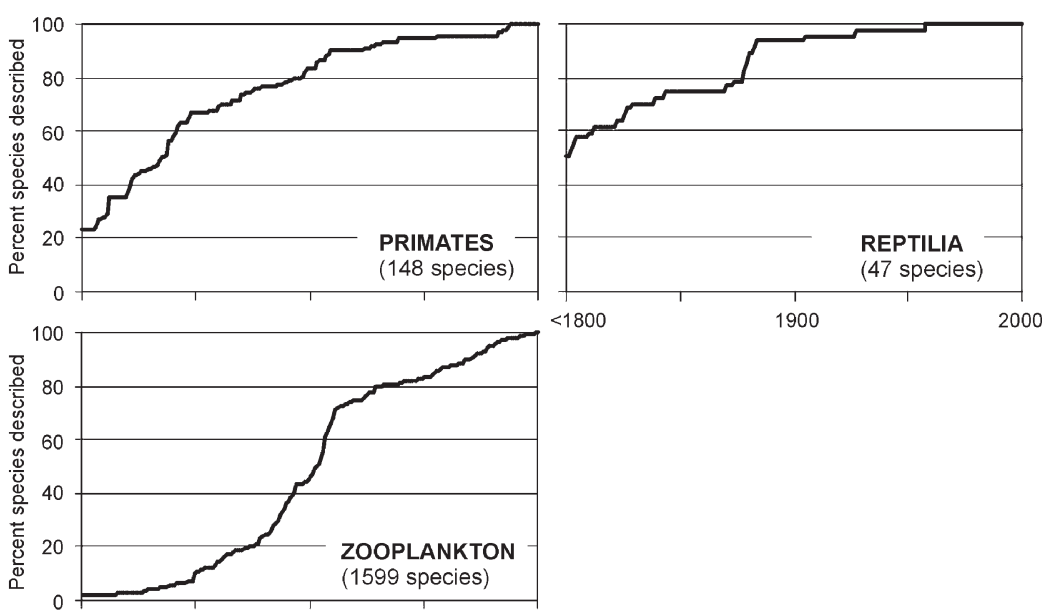

$<1800$

1900

2000
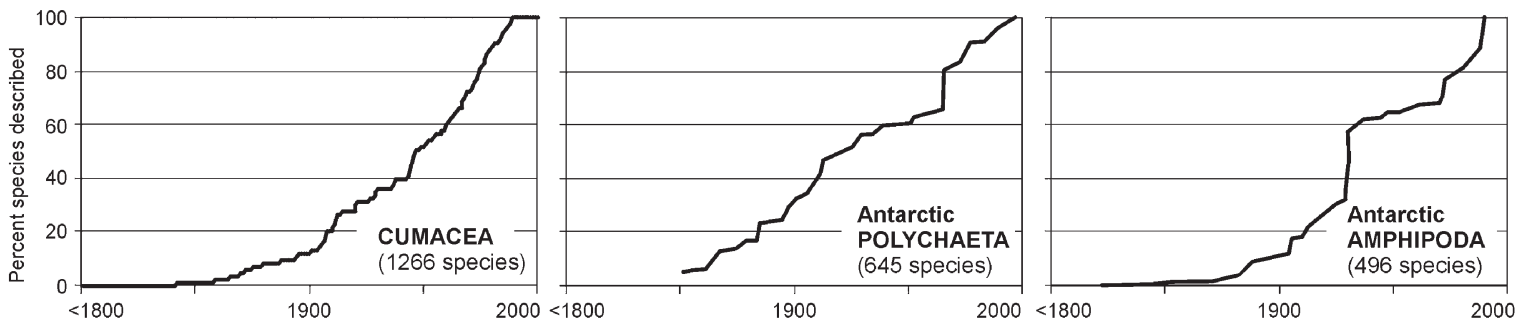

FIG. 3. - Cumulative percentage curves of species description rates for several animal groups. Data sources are, Primates: Groves (1993), Reptilia: Noreña (1999, reptiles from the Iberian Peninsula), zooplankton: Boltovskoy (1999a), Cumacea: Bacescu (1988, includes 4 families from the World Ocean), Antarctic Polychaeta and Amphipoda: Clarke and Johnston (2003).

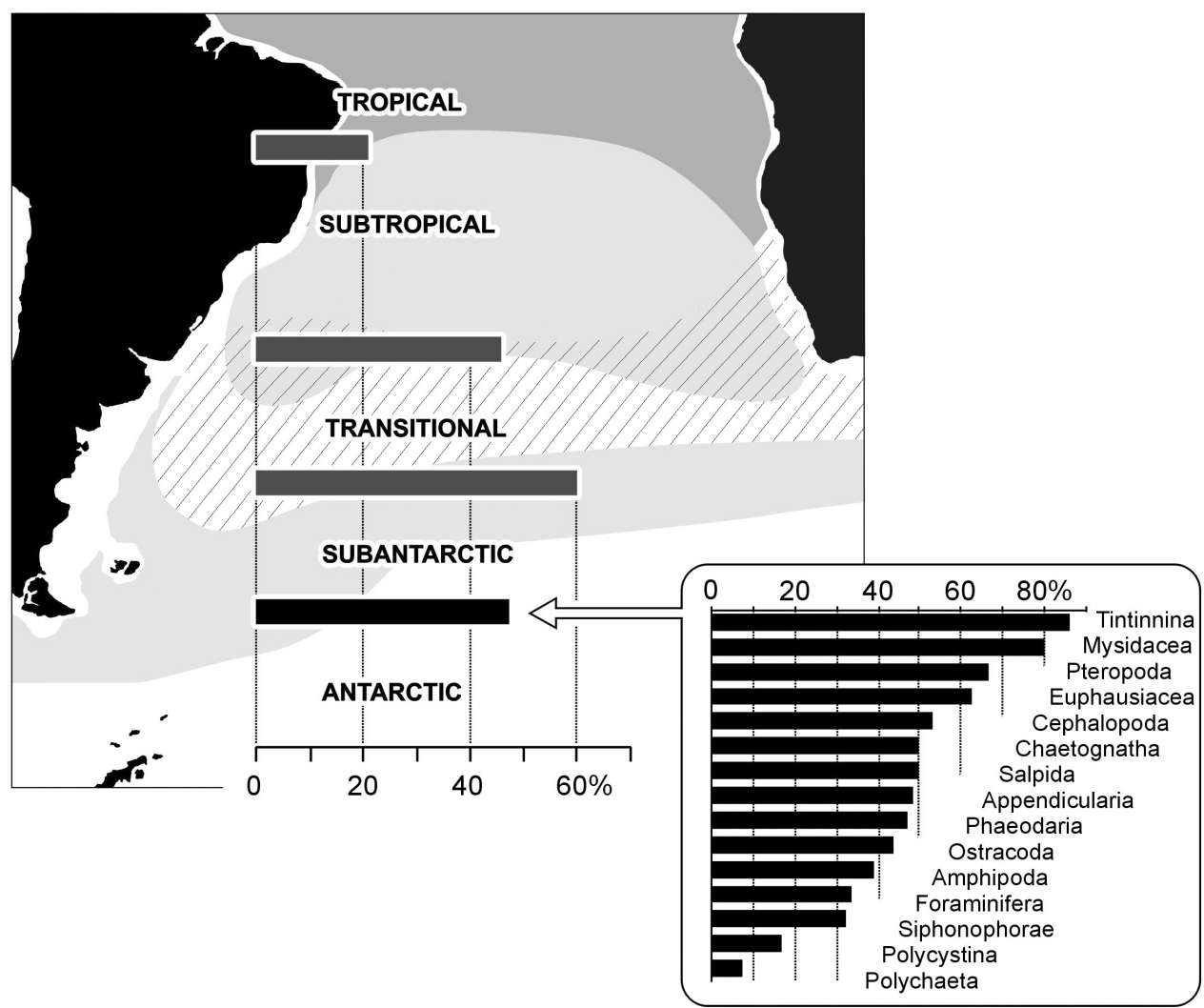

FIG. 4. - Species restricted to either side of each of the major biogeographic boundaries as a proportion of the totals recorded for the South Atlantic. Inset graph shows same figures for the Subantarctic-Antarctic limit broken down by major taxonomic group. Data from Boltovskoy (1999a). 
Foraminifera
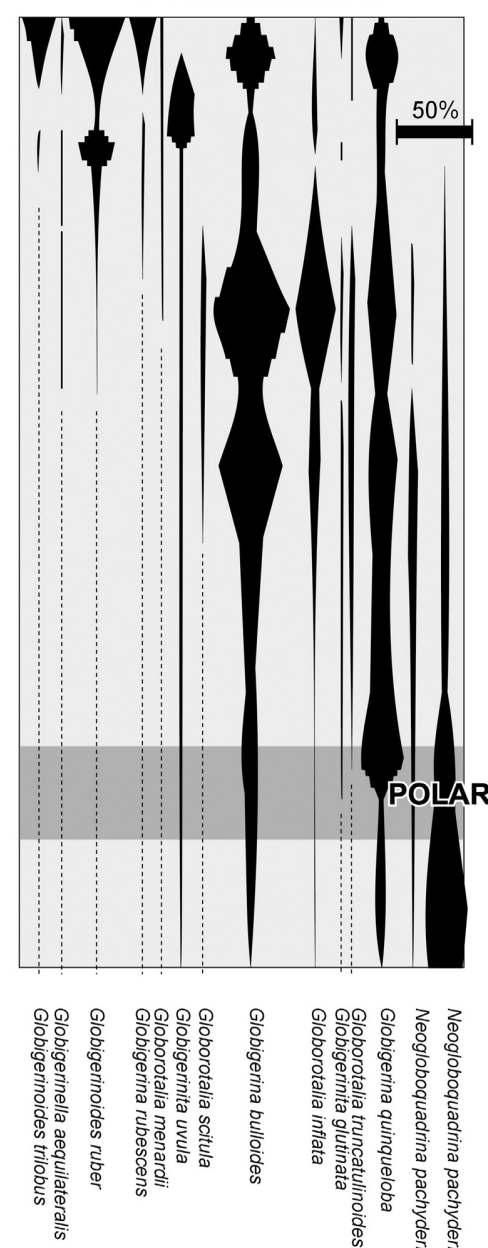

Tintinnina

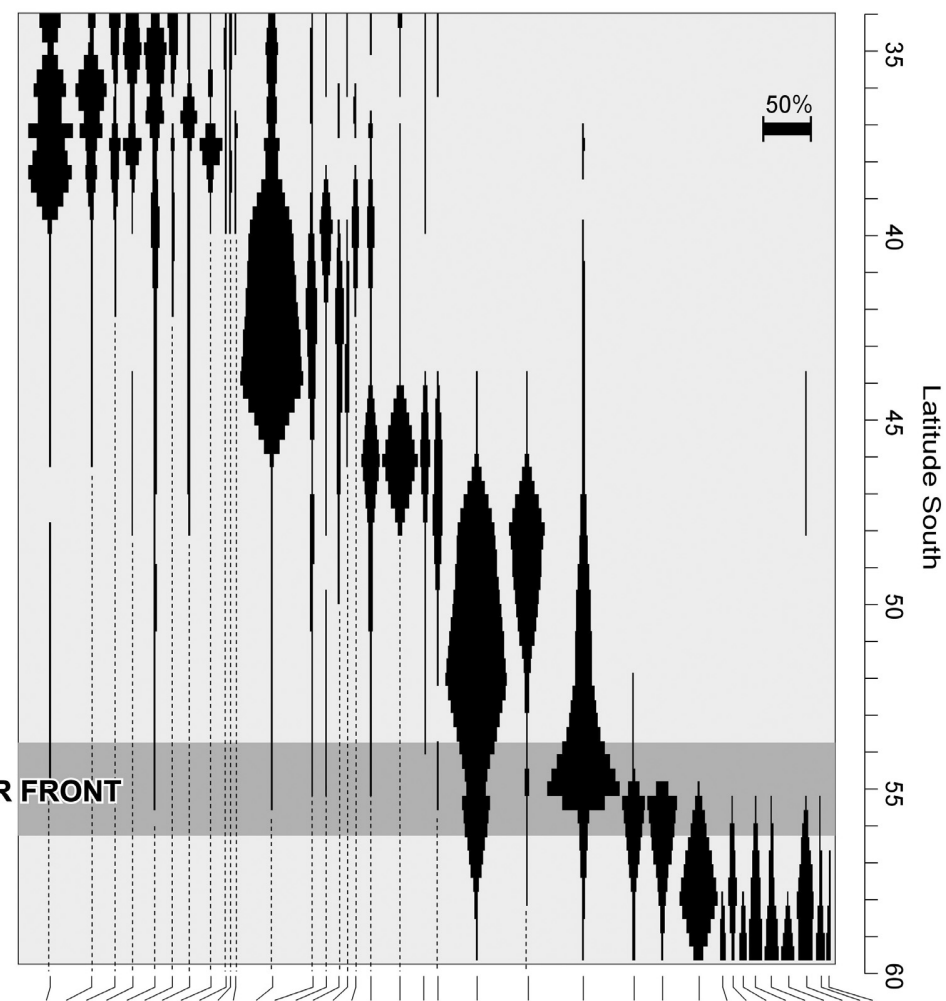

8
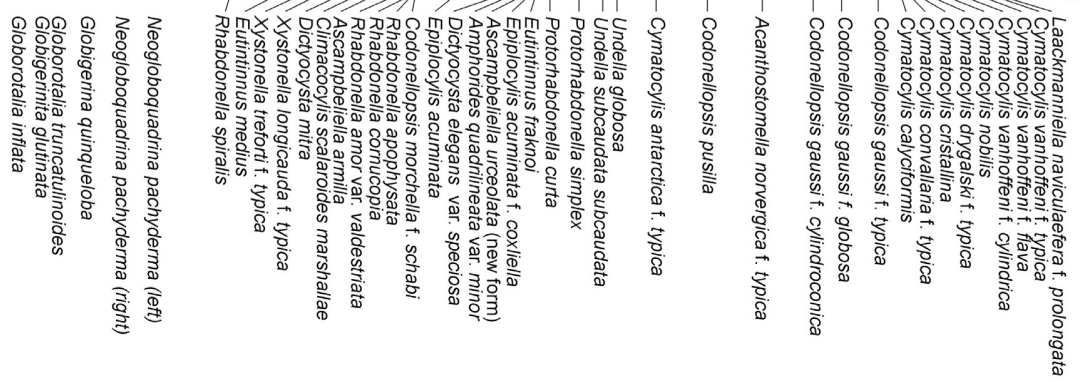

FIG. 5. - Latitudinal distribution of planktonic foraminifers and tintinnids along a transect of plankton samples (integrated data for vertically stratified tows down to $100 \mathrm{~m}$ from 22 stations between 34 and $60^{\circ} \mathrm{S}$, along $51-56^{\circ} \mathrm{W}$, in November 1994). Data from Boltovskoy et al. (2000, Foraminifera) and Thompson et al. (1999, Tintinnina).

often regarded as one of the sharpest and best defined biogeographic barriers in the World Ocean.

For benthic invertebrates, reported degrees of Antarctic endemism vary greatly between groups, but are usually high. Arntz et al. (1997) found values between 35\% (scleractinian corals) and ca. $90 \%$ (pycnogonids). Other taxa show intermediate values (e.g., De Broyer and Jazdzewski, 1996; Brandt et al., 1999; De Broyer and Rauschert, 1999). The distribution of zooplanktonic species, on the other hand, is much less affected by this boundary. Figure 4 illustrates the numbers of species whose latitudinal distribution ranges are interrupted by the Polar Front as a proportion of the species present on either side of it. For comparative purposes, the same figure is also given for the other three major faunal boundaries in the South Atlantic.
Two interesting observations emerge from these data. First, contrary to prediction on the basis of benthic data, the Polar Front boundary is more important than the Tropical-Subtropical Limit, but almost equivalent to the Subtropical-Transitional Limit, and weaker in biogeographic terms than the Transitional-Subantarctic. In other words, Antarctic and Subantarctic waters share about as many species as the Subtropical and the Transition zones, and are more alike than the Transitional and the Subantarctic areas. Second, the degree to which different groups are affected by this front is extremely variable: none of the species of pelagic Foraminifera that inhabit the cold waters of the South Atlantic (Subantarctic and/or Antarctic) are restricted to either side of this boundary, whereas among the Tintinnina $\mathrm{ca} .90 \%$ of the cold water species do not 


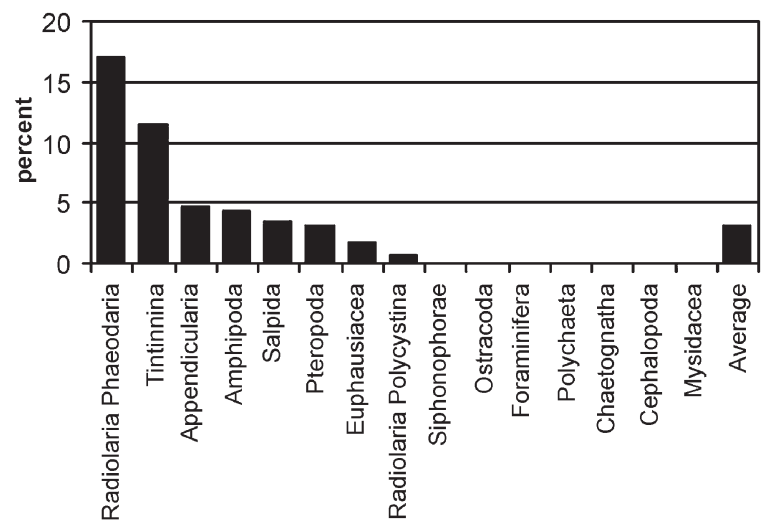

FIG. 6. - Approximate proportions of Antarctic endemic species in selected zooplanktonic groups. No column means no endemics known. Data from Boltovskoy (1999a, Atlantic sector only).

cross this limit (Fig. 5). This trend, in addition to contrasts between the various groups considered, is illustrated by data shown in Figure 6 .

It should be mentioned that the above perception of the low degree of isolation of Antarctic zooplankton is probably somewhat biased by the fact that our records include not only the core areas of the species, but also their expatriation areas. The former are restricted to regions where the species reproduce and are able to maintain self-sustaining populations, whereas expatriation regions, where the animals merely survive, can be significantly larger (Beklemishev, 1969). Although benthic organisms are not free from this error either, we anticipate that the naturally much higher mobility of plankton can enhance this bias. Better coverage of the seas around the often poorly sampled Southern Ocean will decrease the proportions of Antarctic endemics. While this is true for both the benthos and the plankton, figures for the former will change more because benthic animals have typically smaller areas.

\section{CONCLUSIONS}

In this review we tried to show that marine zooplanktonic species are comparatively very few in number, and that a large proportion of them have already been discovered, partly because their geographic ranges are very wide.

Since its inception as an issue of major international interest at the National Forum on BioDiversity in Washington, DC, in 1986, the notion of biodiversity has had many formal definitions (Clarke and Johnston, 2003), yet for most of them assessment of the numbers of species is a key component of the concept. Aside from their theoretical and conceptual interest, precise estimates of the numbers of species awaiting discovery have a fundamental practical value insofar as they are a key consideration for the allocation of resources. However, in these discussions absolute numbers are rarely placed in context, which makes comparisons equivocal. Despite the fact that oceans cover over $70 \%$ of the earth's surface, they host only about 200,000 of the ca. 1,800,000 species described (Grassle, 2001). The plankton, in turn, occupies over $99 \%$ of the space available to marine creatures, and although a very large proportion of the few planktonic species have the largest distributional areas on the planet, they only represent a minor percentage $(<5 \%)$ of the oceanic biodiversity. These contrasts suggest that at least some of the mechanisms important in structuring life and driving evolutionary processes in other communities are not applicable to the plankton, and that the ecological relevance of plankton is not paralleled by its diversity. Furthermore, the fact that marine planktonic inventories are probably better documented than those of several terrestrial and freshwater habitats may yield the wrong notion that we have a better understanding of them as a whole.

This is clearly not the case. Aside from the fact that for several zooplanktonic groups classification systems are in a very serious state of disarray, distributional and ecologic data are very scarce for almost all planktonic organisms. There are entire classes for which there is not a single species whose world wide distribution in the plankton has been mapped (e.g. Acantharia, Polycystina, Phaeodaria). Our current understanding of vertical distribution and abundance patterns, trophic relationships, consequences of marine planktonic bioinvasions, plankton-mediated global elemental cycles and patterns of endemism is still in its very infancy. Some of the overarching questions posed over 30 years ago, such as how planktonic distributional patterns arose, how they are maintained, and how rare species survive (e.g. McGowan, 1974) are still largely unresolved. The problem of rare species is particularly relevant because, while comprising the vast majority of the oceanic biodiversity (e.g. McGowan and Walker, 1993), they are the most vulnerable to both natural and human disturbance and extinction (Angel, 1996). These rare species are also the ones that are most incompletely accounted for in our current inventories. Thus, our understanding of the biodiversity (in the broad sense) of the marine pelagial is 
not better than that of terrestrial or freshwater communities, but the approaches that will be required in order to improve this knowledge are different from those necessary for other plant and animal groups.

\section{ACKNOWLEDGEMENTS}

The authors are indebted to the following colleagues for providing useful published as well as unpublished information: M. Angel (UK), P. Cornelius (UK), B. Eschmeyer (USA), G. Esnal (Argentina), M.A. Fernández Álamo (México), M. Gibbons (South Africa), R. Gibson (UK), J. Grieve (New Zealand), L. Jacobsen (USA), L. Markhaseva (Russia), H. Mianzan (Argentina), M. Mudry (Argentina), M. Murano (Japan), M. P. Olivar (Spain), W. Petz (Austria), P. Pugh (UK), C. Razouls (France), D. Roccatagliata (Argentina), S. van der Spoel (Holland), and G. Tell (Argentina).

\section{REFERENCES}

Alder, V.A. - 1999. Tintinnoinea. In: D. Boltovskoy (ed.), South Atlantic zooplankton, pp. 321-384. Backhuys, Leiden.

Angel, M.V. - 1996. Chapter 15: Ocean diversity. In: C.P. Summerhayes and S.A. Thorpe (eds.), Oceanography. An illustrated guide, pp. 228-243. Wiley, New York.

Angel, M.V. - 1999. Ostracoda. In: D. Boltovskoy (ed.), South Atlantic zooplankton, pp. 815-868. Backhuys, Leiden.

Arntz, W.E., J. Gutt and M. Klages. - 1997. Antarctic marine biodiversity: an overview. In: B. Battaglia et al. (eds.), Antarctic communities: species, structure and survival, pp. 3-14. Cambridge Univ. Press, Cambridge.

Bacescu, M. - 1988. Crustaceorum catalogus. Pars 7. Cumacea I (Fam. Archaeocumatidae, Lampropidae, Bodotriidae, Leuconidae). SPB Acad. Publ., The Hague.

Bé, A.W.H. and D.S. Tolderlund. - 1971. Distribution and ecology of living planktonic Foraminifera in surface waters of the Atlantic and Indian oceans. In: W.R. Riedel and B.M. Funnell (eds.), The micropalaeontology of oceans, pp. 105-149. Cambridge Univ. Press, Cambridge.

Beklemishev, K.V. - 1969. Ekologiya i biogeografiya pelagiali. Nauka, Moskva.

Boltovskoy, D. - 1998. Classification and distribution of South Atlantic recent polycystine Radiolaria. Palaeontologia Electronica, 1(2): $116 \mathrm{pp} ., 2.5 \mathrm{MB}$. http://www-odp.tamu.edu/ paleo/1998_2/boltovskoy/issue2.htm.

Boltovskoy, D. (ed.). - 1999a. South Atlantic zooplankton. Backhuys, Leiden.

Boltovskoy, D. - 1999b. Radiolaria Polycystina. In: D. Boltovskoy (ed.), South Atlantic zooplankton, pp. 149-212. Backhuys, Leiden.

Boltovskoy, D. - 2000. Diversidad y biogeografía del zooplancton del Atlántico Sur. An. Acad. Nac. Cienc. Ex. Fís. Natur., 51: 111-136.

Boltovskoy, E., D. Boltovskoy and F. Brandini. - 2000. Planktonic Foraminifera from south-western Atlantic epipelagic waters: abundance, distribution and year-to-year variations. J. Mar. Biol. Ass. U.K., 79: 203-213.

Boltovskoy, D., N. Correa and A. Boltovskoy. - 2003. Marine zooplanktonic diversity: a view from the South Atlantic. Oceanol. Acta, 25: 271-278

Boltovskoy, D., M.J. Gibbons, L. Hutchings and D. Binet. - 1999. General biological features of the South Atlantic. In: D.
Boltovskoy (ed.), South Atlantic zooplankton, pp. 1-42. Backhuys, Leiden.

Botnikov, V.N. - 1963. Geographical position of the Antarctic Convergence zone in the Pacific Ocean. Sov. Ant. Inf. Bull., 4: 324327.

Bouillon, J. - 1999. Hydromedusae. In: D. Boltovskoy (ed.), South Atlantic zooplankton, pp. 385-466. Backhuys, Leiden.

Brandt, A., K. Linse and U. Mühlenhardt-Siegel. - 1999. Biogeography of Crustacea and Mollusca of the Subantarctic and Antarctic regions. Sci. Mar., 63(Suppl. 1): 383-389.

Briggs, J.C. - 1996. Global biogeography. Elsevier, Amsterdam.

Bucklin, A., B.W. Frost, J. Bradford Grieve, L.D. Allen, and N.J. Copley. - 2003. Molecular systematic assessment of thirty-four calanoid copepod species of the Calanidae and Clausocalanidae using DNA sequences of mtCOI and nuclear 18S rRNA. Mar. Biol., 142: 333-343.

Bucklin, A., T.C. La Jeunesse, E. Curry, J. Wallinga, and K. Garrison. - 1996. Molecular genetic diversity of the copepod Nannocalanus minor: Genetic evidence of species and population structure in the North Atlantic Ocean. J. Mar. Res., 54: 285310.

Casanova J.P. - 1999. Chaetognatha. In: D. Boltovskoy (ed.), South Atlantic zooplankton, pp. 1353-1374. Backhuys, Leiden.

Clarke, A. and N.M. Johnston. - 2003. Antarctic marine benthic diversity. Oceanogr. Mar. Biol., 41: 47-114.

CMarZ (Census of Marine Zooplankton). - 2004. Science Plan. Prepared by the participants of a Census of Marine Life planning workshop for a census of the plankton, Portsmouth, New Hampshire USA, 17-22 March 2004.

Costello, M.J., C.S. Emblow and B.E. Picton. - 1996. Long term trends in the discovery of marine species new to science which occur in Britain and Ireland. J. Mar. Biol. Ass. UK, 76: 255257.

DeBroyer, C. and K. Jazdzewski. - 1996. Biodiversity of the Southern Ocean: towards a new synthesis for the Amphipoda (Crustacea). Boll. Mus. Civico Storia Natur., 20: 547-568.

DeBroyer, C. and M. Rauschert. - 1999. Faunal diversity of the benthic amphipods (Crustacea) of the Magellan region as compared to the Antarctic (preliminary results). Sci. Mar., 63 (Suppl. 1): 281-293.

DeVargas, C., R. Norris, R. Zaninetti, S.W. Gibb and J. Pawlowski. - 1999. Molecular evidence of cryptic speciation in planktonic foraminifers and their relation to oceanic provinces. Proc. Natl. Acad. Sci., 96: 2864-2868.

DeVargas, C., A.G. Sáez, L.K. Medlin and H.R. Thierstein. - 2004. Super-Species in the calcareous plankton. In: H.R. Thierstein and J.R. Young (eds.), Coccolithophores: from molecular processes to global impact, pp. 271-298. Springer-Verlag.

Esnal, G. - 1999. Appendicularia. In: D. Boltovskoy (ed.), South Atlantic zooplankton, pp. 1375-1399. Backhuys, Leiden.

Esnal, G. and C. Daponte. 1999. - Salpida. In: D. Boltovskoy (ed.), South Atlantic zooplankton, pp. 1423-1444. Backhuys, Leiden.

Gibbons M.J., V.A. Spiridonov and G.A. Tarling. - 1999. Euphausiacea. In: D. Boltovskoy (ed.), South Atlantic zooplankton, pp. 1241-1280. Backhuys, Leiden.

Goetze, E. - 2003. Cryptic speciation on the high seas; global phylogenetics of the copepod family Eucalanidae. P. Roy. Soc. London B-BIO, 270: 2321-2331.

Grassle, J.F. - 2001. Marine ecosystems. In: S.A. Levin (ed.), Encyclopaedia of Biodiversity, pp. 13-25. Academic Press, San Diego.

Grassle, J.F. and N.J. Maciolek. - 1992. Deep sea species richness: regional and local diversity estimates from quantitative bottom samples. Am. Nat., 139: 313-341.

Groves, C.P. - 1993. Order Primates. In: D.E. Wilson and D.M. Reeder (eds.), Mammal species of the world: a taxonomic and geographic reference, pp. 243-277. Smithsonian Inst. Press, Washington.

Gutt, J., B.I. Sirenko, I.S. Smirnov and W.E. Arntz. - 2004.- How many macrozoobenthic species might inhabit the Antarctic shelf? Ant. Sci., 16: 11-16.

Held, C. - 2005. Cryptic speciation in the giant Antarctic isopod Glyptonotus antarcticus (Isopoda, Valvifera, Chaetiliidae). Sci. Mar. 69(Suppl. 2): 175-181.

Hemleben C., M. Spindler and O.R. Anderson. - 1989. Modern planktonic Foraminifera. Springer, New York.

Hutchinson, G.E. - 1961. The paradox of the plankton. Am. Nat., 95: 137-145. 
Kemle von Mücke, S. and C. Hemleben. - 1999. Foraminifera. In: D. Boltovskoy (ed.), South Atlantic zooplankton, pp. 43-76. Backhuys, Leiden.

Kling, S.A. and D. Boltovskoy. - 1999. Radiolaria Phaeodaria. In: D. Boltovskoy (ed.), South Atlantic zooplankton, pp. 213-264. Backhuys, Leiden.

McGowan, J.A. - 1974. The nature of oceanic ecosystems. In: C.B. Miller (ed.), The biology of the oceanic Pacific, pp. 9-28. Oregon State Univ. Press, Corvallis.

McGowan, J.A. and P.W. Walker. - 1993. Pelagic diversity patterns. In: R.E. Ricklefs and D. Schluter (eds.), Species diversity in ecological communities. Historical and geographic perspectives, pp. 203-214. Univ. Chicago Press, Chicago.

Murano, M. - 1999. Mysidacea. In: D. Boltovskoy (ed.), South Atlantic zooplankton, pp. 1099-1140. Backhuys, Leiden.

Nesis, K.- 1999. Cephalopoda. In: D. Boltovskoy (ed.), South Atlantic zooplankton, pp. 707-795. Backhuys, Leiden.

Noreña, C. - 1999. Fauna Iberica [http://www.faunaiberica.mncn.csic.es/htmlfauna/faunibe/zoolist/platyhelm/turbe llaria.html]

Paxton, C.G.M. - 1998. A cumulative species description curve for large open water marine animals. J. Mar. Biol. Ass. UK, 78: 1389-1391.

Peterson, R.G. and L. Stramma. - 1991. Upper level circulation in the South Atlantic Ocean. Progr. Oceanogr., 26: 1-73.

Pierrot-Bults, A.C. and S. Van del Spoel. - 1979. Speciation in macrozooplankton. In: S. Van del Spoel and A.C. Pierrot-Bults (eds.), Zoogeography and diversity of plankton, pp. 144-167. Bunge, Utrecht.

Pugh, P. - 1999. Siphonophorae. In: D. Boltovskoy (ed.), South Atlantic zooplankton, pp. 467-512. Backhuys, Leiden.

Sournia, A., M.J. Chretiennot-Dinet and M. Ricard. - 1991. Marine phytoplankton: how many species in the world ocean? J. Plankton Res., 13: 1093-1099.

Spoel, S. van der and J.R. Dadon. - 1999. Pteropoda. In: D. Boltovskoy (ed.), South Atlantic zooplankton, pp. 649-706. Backhuys, Leiden.

Thompson, G.A., V.A. Alder, D. Boltovskoy and F. Brandini. 1999. Abundance and biogeography of tintinnids (Ciliophora) and associated microzooplankton in the southwestern Atlantic Ocean. J. Plankton Res., 21: 1265-1298.

Thuesen, E. and M.A. Fernández Alamo. - 1999. Polychaeta. In: D. Boltovskoy (ed.), South Atlantic zooplankton, pp. 595-620. Backhuys, Leiden.

Venrick, E.L. - 1986. Patchiness and the paradox of plankton. In: A.C. Pierrot-Bults, S. van der Spoel, B.J. Zahuranec and R.K. Johnson (eds.), Pelagic biogeography, pp. 261-265. UNESCO Tech. Pap. Mar. Sci., 49.

Vinogradov, G. - 1999. Amphipoda. In: D. Boltovskoy (ed.), South Atlantic zooplankton, pp. 1141-1240. Backhuys, Leiden.

Zenkevitch, L.A. - 1960. Spetzialnaya kolichestvennaya kharakteristika glubokovodnoi zhizni v okeane. Izv. Akad. Nauk SSSR, Ser. Geograf., 2: 10-16. 